\title{
Effects of Nitrogen, Phosphorus, Potassium, Calcium, or Magnesium Deficiency on Growth and Photosynthesis of Eustoma
}

\author{
Chang-Tsern Chen, Ching-Lung Lee, and Der-Ming Yeh ${ }^{1}$ \\ Department of Horticulture and Landscape Architecture, National Taiwan \\ University, Taipei, Taiwan
}

Additional index words. hydroponics, photosystem II, shoot-root dry weight ratio, tipburn

\begin{abstract}
Growth and photosynthetic parameters were measured in Eustoma grandiflorum (Raf.) Shinn. 'Umihonoka' grown hydroponically under nitrogen (N), phosphorus $(\mathrm{P})$, potassium $(\mathrm{K})$, calcium $(\mathrm{Ca})$, or magnesium $(\mathrm{Mg})$ deficiency in $1 / 2$ strength of modified Johnson's solution. Plant height, node number, and leaf area were all reduced under $\mathrm{N}, \mathrm{P}, \mathrm{K}$, and $\mathrm{Ca}$ deficiencies but not under $\mathrm{Mg}$ deficiency as compared with plants grown in the complete nutrient solution. Shoot and root dry weight were reduced in the $\mathrm{N}-$, P-, K-, and Ca-deficient treatments, whereas root but not shoot dry weight was lowered by Mg-deficient treatment. Shoot-to-root dry weight ratio decreased under $\mathbf{N}$ and $P$ deficiencies, increased under $K$ and $M g$ deficiency, but was not altered under $\mathrm{Ca}$ deficiency. Decreased net photosynthetic rate $(P n)$ of $\mathrm{N}$-, P-, and K-deficient leaves was all related to lower stomatal conductance $\left(g_{S}\right)$, whereas $\mathrm{N}$-deficient leaves also accompanied by a higher intercellular carbon dioxide concentration $(\mathrm{Ci})$. The Mg-deficient treatment did not alter chlorophyll fluorescence $F \mathbf{v} / F_{\mathrm{m}}$, maximal fluorescence $(F \mathrm{~m})$, or minimal fluorescence $(F \mathrm{~F})$. Decreased $F \mathrm{v} / F \mathrm{~m}$ of $\mathrm{N}$-, P-, $\mathrm{K}$-, and Ca-deficient leaves was all related to lower $F \mathrm{~m}$, whereas $\mathrm{N}$ - and $\mathrm{P}$-deficient leaves also accompanied by lower $\boldsymbol{F o}$. A key was developed for the identification of $\mathrm{N}, \mathrm{P}, \mathrm{K}, \mathrm{Ca}$, and $\mathrm{Mg}$ deficiency symptoms.
\end{abstract}

Eustoma grandiflorum (Raf.) Shinn. is native to the alkaline soils in Texas, Arizona, and Colorado (Croft and Nelson, 1998), and its cultivation has extended worldwide. Many growers in Taiwan and Japan reduce irrigation before harvesting the flowers to decrease $g_{\mathrm{S}}$ for a better water balance and a longer vase life. However, preharvest-deficit irrigation may limit nutrient supply or availability because Eustoma plants require high nutrient levels (Frett et al., 1988; Marchese et al., 2005) and continue to accumulate dry matter and minerals after flower bud visibility (de Camargo et al., 2004; Ushio and Fukuta, 2010). Small yellow specks are often seen on the lower leaves in Eustoma after flower bud visibility, suggesting a certain level of nutrient deficiency. Characterization of plant development and nutrient deficiency symptoms could aid in diagnosing nutrient disorders and distinguishing nutrient imbalances from other disorders caused by pathogens, chemical damage, or other stresses.

Frett et al. (1988) reported that $\mathrm{N}$ deficiency reduced lateral branches and chlorophyll concentration, whereas $\mathrm{Ca}$ deficiency reduced

Received for publication 31 Jan. 2018. Accepted for publication 3 Apr. 2018

We wish to thank Tzu-Yao Wei for his assistance with the study.

This paper is a portion of a dissertation submitted by Chang-Tsern Chen.

${ }^{1}$ Corresponding author. E-mail: dmyeh@ntu.edu. tw. shoot dry weight and caused abortion of the apical meristem and young flower buds in four Eustoma cultivars. Eustoma with $50 \mathrm{~g} \cdot \mathrm{m}^{-3} \mathrm{~N}$ had lower $P n, g_{\mathrm{S}}$, and transpiration rates $(E)$, and higher $\mathrm{Ci}$ than those with 250 or $300 \mathrm{~g} \cdot \mathrm{m}^{-3} \mathrm{~N}$ (Marchese et al., 2005). No information is available on effects of other macronutrient deficiencies on growth and photosynthesis for Eustoma. In other plant species, nutrient deficiencies not only reduce the provision of photosynthates, but also alter the shoot-root partitioning of photoassimilates (Farhat et al., 2016; Hermans et al., 2006).

The objectives of this study were to measure growth and photosynthesis of Eustoma under $\mathrm{N}, \mathrm{P}, \mathrm{K}, \mathrm{Ca}$, or $\mathrm{Mg}$ deficiency in a nutrient solution. We also investigated nutrient deficiency on visual deficiency symptoms and shoot-root ratios, which are important aspects of Esutoma used as a cut flower or potted flowering plant.

\section{Materials and Methods}

Plug seedlings of Eustoma 'Umihonoka' were selected for uniformity at the three to four leaf-pair stage and rinsed several times with deionized water to remove the root medium, with the least possible injury to the roots. The plants were then placed into the various nutrient-deficient treatments in 3-L plastic containers fitted with Styrofoam lids with holes to support the plants.

Apart from the complete nutrient solution (control), nutrient-deficient treatments comprised $-\mathrm{N},-\mathrm{P},-\mathrm{K},-\mathrm{Ca}$, and $-\mathrm{Mg}$ in $1 / 2$ strength of modified Johnson's solution (Johnson et al., 1957). Nutrient solutions were formulated to eliminate the particular nutrients, without changing the concentration of others. This was achieved by replacing the associated missing anions or cations using an appropriate sodium or chloride compound (Table 1). To prevent salt accumulation or nutrient depletion, nutrient solutions were changed weekly. The $\mathrm{pH}$ and electrical conductivity (EC) of all nutrient solutions were measured using a $\mathrm{pH}$ and conductivity meter (IQ170; IQ Scientific Instruments, Carisad, CA) and adjusted to $\mathrm{pH} 6.5 \pm 0.2$ following the methods described by Kirkby and Mengel (1967). The $\mathrm{EC}$ of nutrient solutions in this study ranged from 0.99 to $1.03 \mathrm{dS} \cdot \mathrm{m}^{-1}$. All plants were grown in a greenhouse with an average noon photosynthetic photon flux $(P P F)$ of $777 \mu \mathrm{mol} \cdot \mathrm{m}^{-2} \cdot \mathrm{s}^{-1}$. The air temperature during the experimental period ranged from 18 to $23{ }^{\circ} \mathrm{C}$, as recommended for Eustoma growth (Harbaugh, 1995; Harbaugh and Woltz, 1991; Islam et al., 2004).

Plant growth (height, node number, leaf area, longest root length, shoot, and root dry weights), relative chlorophyll concentration, and photosynthetic parameters were measured after treatment for $56 \mathrm{~d}$. Total leaf area was determined by a leaf area meter (LI-COR 3000; LI-COR, Lincoln, NE). Relative chlorophyll concentration of the recently fully expanded leaves was gauged in situ with a chlorophyll meter (SPAD-502; Minolta Camera, Tokyo, Japan). Shoots and roots were oven-dried at $68{ }^{\circ} \mathrm{C}$ for $72 \mathrm{~h}$ to determine their dry weights.

The recently fully expanded leaf was used to measure the photosynthetic parameters. A portable photosynthesis system (LI-6400 XT; LI-COR) was used to measure $P n, g_{\mathrm{S}}$, and $\mathrm{Ci}$ under $1000 \mu \mathrm{mol} \cdot \mathrm{m}^{-2} \cdot \mathrm{s}^{-1} P P F$. Carbon dioxide concentration entering the leaf chamber and the leaf temperature were $380 \mu \mathrm{mol} \cdot \mathrm{mol}^{-1}$ and $25 \pm 0.2{ }^{\circ} \mathrm{C}$, respectively. Minimal fluorescence was determined after $30 \mathrm{~min}$ dark adaptation at $20^{\circ} \mathrm{C}$, whereas $F \mathrm{~m}$ was measured after saturation pulse with a modulated light MiniPam (Teaching-PAM chlorophyll fluoremeter; Heinz Walz, Effeltrich, Germany). The fluorescence ratio $F \mathrm{~V} / F \mathrm{~m}$, with $F_{\mathrm{V}}=$ $F \mathrm{~m}-F_{\mathrm{O}}$ being the variable fluorescence, was calculated.

The nutrient treatments were arranged in a completely randomized design, with three replications per treatment and six plants per replication. Means of growth and photosynthetic parameters were separated by $t$ test for comparison of means with the control.

\section{Results and Discussion}

Complete nutrient solution (control). Eustoma plants with the complete nutrient solution had maximum growth as measured by plant height, node number, total leaf area, SPAD-502 reading, and plant dry weights (Tables 2 and 3). Plants grew well and without any deficiency symptoms (Fig. 1), 
Table 1. Nutrient formulations used to induce nitrogen $(\mathrm{N})$, phosphorus $(\mathrm{P})$, potassium $(\mathrm{K})$, calcium $(\mathrm{Ca})$, or magnesium $(\mathrm{Mg})$ deficiencies in Eustoma 'Umihonoka'.

\begin{tabular}{|c|c|c|c|c|c|c|c|}
\hline \multirow[b]{2}{*}{ Nutrient formulation } & \multirow[b]{2}{*}{ Rate (mM) } & \multicolumn{6}{|c|}{ Treatment } \\
\hline & & Control & $-\mathrm{N}$ & $-\mathrm{P}$ & $-\mathrm{K}$ & $-\mathrm{Ca}$ & $-\mathrm{Mg}$ \\
\hline$\overline{\mathrm{NaNO}_{3}}$ & 3 & - & - & + & + & + & - \\
\hline $\mathrm{KNO}_{3}$ & 3 & + & - & + & - & + & + \\
\hline $\mathrm{NH}_{4} \mathrm{NO}_{3}$ & 1 & - & - & + & - & + & - \\
\hline $\mathrm{Ca}\left(\mathrm{NO}_{3}\right)_{2}$ & 2 & + & - & - & + & - & + \\
\hline $\mathrm{NH}_{4} \mathrm{H}_{2} \mathrm{PO}_{4}$ & 1 & + & - & - & + & - & - \\
\hline$\left(\mathrm{NH}_{4}\right)_{2} \mathrm{SO}_{4}$ & 0.5 & - & - & - & - & - & + \\
\hline $\mathrm{NaH}_{2} \mathrm{PO}_{4}$ & 1 & - & + & - & - & + & + \\
\hline $\mathrm{KCl}$ & 3 & - & + & - & - & - & - \\
\hline $\mathrm{MgSO}_{4}$ & 0.5 & + & + & + & + & + & - \\
\hline $\mathrm{CaCl}_{2}$ & 2 & - & + & + & - & - & - \\
\hline $\mathrm{H}_{3} \mathrm{BO}_{3}$ & 0.025 & + & + & + & + & + & + \\
\hline $\mathrm{MnSO}_{4}$ & 0.005 & + & + & + & + & + & + \\
\hline $\mathrm{ZnSO}_{4}$ & 0.002 & + & + & + & + & + & + \\
\hline $\mathrm{CuSO}_{4}$ & 0.0005 & + & + & + & + & + & + \\
\hline $\mathrm{H}_{2} \mathrm{MoO}_{4}$ & 0.0001 & + & + & + & + & + & + \\
\hline $\mathrm{FeSO}_{4}$ & 0.004 & + & + & + & + & + & + \\
\hline Fe-EDTA & 0.004 & + & + & + & + & + & + \\
\hline
\end{tabular}

Table 2. Effects of nitrogen $(\mathrm{N})$, phosphorus $(\mathrm{P})$, potassium $(\mathrm{K})$, calcium $(\mathrm{Ca})$, or magnesium $(\mathrm{Mg})$ deficiencies on plant height, node number, leaf area, SPAD-502 reading of the recently fully expanded leaves, and root length in Eustoma 'Umihonoka' grown hydroponically.

\begin{tabular}{lccccc}
\hline Treatment & $\mathrm{Ht}(\mathrm{cm})$ & Node number & Leaf area $\left(\mathrm{cm}^{2}\right)$ & SPAD-502 reading & Root length $(\mathrm{cm})$ \\
\hline Control & 18.5 & 12.6 & 225.30 & 55.3 & 24.1 \\
$-\mathrm{N}$ & $2.2^{* * *}$ & $5.0^{* * *}$ & $24.00^{* * *}$ & $29.9^{* * *}$ & $42.5^{* * *}$ \\
$-\mathrm{P}$ & $5.3^{* * *}$ & $7.0^{* * *}$ & $39.60^{* * *}$ & $52.4 \mathrm{NS}$ & $51.6^{* * *}$ \\
$-\mathrm{K}$ & $9.5^{* * *}$ & $11.0^{* * *}$ & $137.35^{* *}$ & $44.3^{* *}$ & $19.6 \mathrm{NS}$ \\
$-\mathrm{Ca}$ & $7.3^{* * *}$ & $8.4^{* * *}$ & $57.75^{* * *}$ & $23.5^{* * *}$ & $7.0^{* *}$ \\
$-\mathrm{Mg}$ & $17.6 \mathrm{NS}$ & $11.8^{*}$ & $272.61 \mathrm{NS}$ & $53.8 \mathrm{NS}$ & $21.3 \mathrm{NS}$ \\
\hline Ns, ${ }^{*},{ }^{* *},{ }^{* * *}$ Nonsignificant or significantly different from the control by $t$ test at $P<0.05,0.01$, or 0.001,
\end{tabular}
respectively.

Table 3. Effects of nitrogen $(\mathrm{N})$, phosphorus $(\mathrm{P})$, potassium $(\mathrm{K})$, calcium $(\mathrm{Ca})$, or magnesium $(\mathrm{Mg})$ deficiencies on shoot and root dry weight, and shoot-root dry weight ratio of Eustoma 'Umihonoka' grown hydroponically.

\begin{tabular}{lccc}
\hline Treatment & Shoot dry wt (g/plant) & Root dry wt (g/plant) & Shoot-root dry wt ratio \\
\hline Control & 1.78 & 0.50 & 3.61 \\
$-\mathrm{N}$ & $0.09^{* * *}$ & $0.17^{* * *}$ & $0.54^{* * *}$ \\
$-\mathrm{P}$ & $0.32^{* * *}$ & $0.21^{* * *}$ & $1.52^{* * *}$ \\
$-\mathrm{K}$ & $0.65^{* * *}$ & $0.13^{* * *}$ & $5.45^{* *}$ \\
$-\mathrm{Ca}$ & $0.40^{* * *}$ & $0.14^{* * *}$ & $2.98 \mathrm{NS}$ \\
$-\mathrm{Mg}$ & $1.75 \mathrm{NS}$ & $0.34^{*}$ & $5.27^{* *}$ \\
\hline $\mathrm{Ns},{ }^{*},{ }^{* *},{ }^{* *}$ Nonsignificant or significantly different from the control by $t$ test at $P<0.05,0.01$, or 0.001,
\end{tabular}
respectively.

Table 4. Effects of nitrogen $(\mathrm{N})$, phosphorus $(\mathrm{P})$, potassium $(\mathrm{K})$, calcium $(\mathrm{Ca})$, or magnesium $(\mathrm{Mg})$ deficiencies on net photosynthetic rate $(P n)$, stomatal conductance $\left(g_{\mathrm{S}}\right)$, and intercellular carbon dioxide concentration ( $\mathrm{Ci}$ ) of the recently fully expanded leaves of Eustoma 'Umihonoka' grown hydroponically.

\begin{tabular}{lccc}
\hline Treatments & $P n\left(\mu \mathrm{mol} \mathrm{CO}_{2} / \mathrm{m}^{2} / \mathrm{s}\right)$ & $g_{\mathrm{S}}\left(\mathrm{mol} \cdot \mathrm{m}^{-2} \cdot \mathrm{s}^{-1}\right)$ & $\mathrm{Ci}\left(\mu \mathrm{mol} \cdot \mathrm{mol}^{-1}\right)$ \\
\hline Control & 14.7 & 0.56 & 320 \\
$-\mathrm{N}$ & $2.2^{* * *}$ & $0.29^{* *}$ & $352^{*}$ \\
$-\mathrm{P}$ & $1.4^{* * *}$ & $0.17^{* * *}$ & $325 \mathrm{NS}$ \\
$-\mathrm{K}$ & $7.5^{*}$ & $0.33^{*}$ & $345 \mathrm{NS}$ \\
$-\mathrm{Ca}$ & $7.4^{*}$ & $0.38 \mathrm{NS}$ & $335 \mathrm{NS}$ \\
$-\mathrm{Mg}$ & $14.7 \mathrm{NS}$ & $0.58 \mathrm{NS}$ & $318 \mathrm{NS}$ \\
\hline $\mathrm{Ns},{ }^{* * *},{ }^{* * *}$ Nonsignificant or significantly different from the control by $t$ test at $P<0.05,0.01$, or 0.001,
\end{tabular}

respectively.

indicating that the $\mathrm{EC}$ and $\mathrm{pH}$ range adopted was appropriate.

The net $\mathrm{CO}_{2}$ assimilation rate of Eustoma plants with the complete nutrient solution was $14.7 \mu \mathrm{mol} \cdot \mathrm{m}^{-2} \cdot \mathrm{s}^{-1}$ (Table 4 ), slightly higher than $9.6-12.2 \mu \mathrm{mol} \cdot \mathrm{m}^{-2} \cdot \mathrm{s}^{-1}$ as reported previously (Hernández-Pérez et al., 2016; Takezaki et al., 2004). By contrast, for nonstressed plants (Bolhar-Nordenkampf et al., 1989).

Nitrogen deficiency. Nitrogen deficiency resulted in stunted growth, with reduced leaf area and SPAD-502 reading, as well as slender roots (Fig. 1; Table 2). Leaf initiation appeared to have stopped. Young and recently developed leaves became uniformly chlorotic, whereas the lower leaves were yellowish. The $\mathrm{N}$ deficiency symptoms are similar to those described for Spathiphyllum (Yeh et al., 2000). Shoot and root dry weight, and shoot-root ratio were all significantly reduced by the $-\mathrm{N}$ treatment (Table 3 ). Similar examples for preferential partitioning of photosynthetic carbon to the roots and decrease in shoot-root ratio are well documented for other species under $\mathrm{N}$ deficiency (Hermans et al., 2006).

Nitrogen-deficient Eustoma plants had lower $P n$ and $g_{\mathrm{S}}$ but higher $\mathrm{Ci}$ than that of the control (Table 4), similar to previous reports (Cechin and Fumis, 2004; Mak and Yeh, 2000; Marchese et al., 2005). Nitrogendeficient plants had lower $F \mathrm{v} / F \mathrm{~m}$ and $F \mathrm{~m}$, but higher $F_{0}$ than the control plants (Table 5), indicating that $\mathrm{N}$ deficiency causes damage to photosystem II functioning in Eustoma. Similar results have been reported for rice (Oryza sativa L.) (Huang et al., 2004).

Phosphorus deficiency. The P-deficient Eustoma plants were shorter and produced fewer nodes, smaller leaf area, but longer roots than those with the complete nutrient solution (Fig. 1; Table 2). The -P treatment reduced $80 \%$ shoot dry weight and $58 \%$ root dry weight and resulted in a decreased shootroot ratio as compared with the control (Table 3). These results are consistent with Mollier and Pellerin (1999) showing that P deficiency quickly and severely reduces leaf growth. Leaf demand for assimilates by leaves is decreased and, thus, more assimilates become available for root growth in a short time. Hermans et al. (2006) showed that the P-deficient plants improve their ability to acquire $\mathrm{P}$ by altering their carbon partitioning to favor root growth, which serves to decrease shoot-root ratio.

Phosphorus-deficient plants had lower $P n$ and $g_{\mathrm{S}}$ than those with complete nutrient solution (Table 4). However, the SPAD-502 reading and $\mathrm{Ci}$ was comparable with that of the control plants (Tables 2 and 4). These results suggest that decreased $P n$ of P-deficient leaves in Eustoma was mainly through stomatal limitation and not caused by reduced chlorophyll concentration. Similar results were reported for sugar beet (Beta vulgaris L.) (Terry and Ulrich, 1973).

Phosphorus-deficient Eustoma plants had lower $F \mathrm{v} / F \mathrm{~m}$ and $F \mathrm{~m}$ but higher $F_{\mathrm{O}}$ than the control plants (Table 5). Similar P deficiency effects on chlorophyll fluorescence parameters were reported for rice (Xu et al., 2007).

Potassium deficiency. Potassium-deficient resulted in reduced plant height, node number, leaf area, and SPAD-502 reading (Fig. 1; Table 2). Small chlorotic specks and marginal necrosis were expressed on the lower 


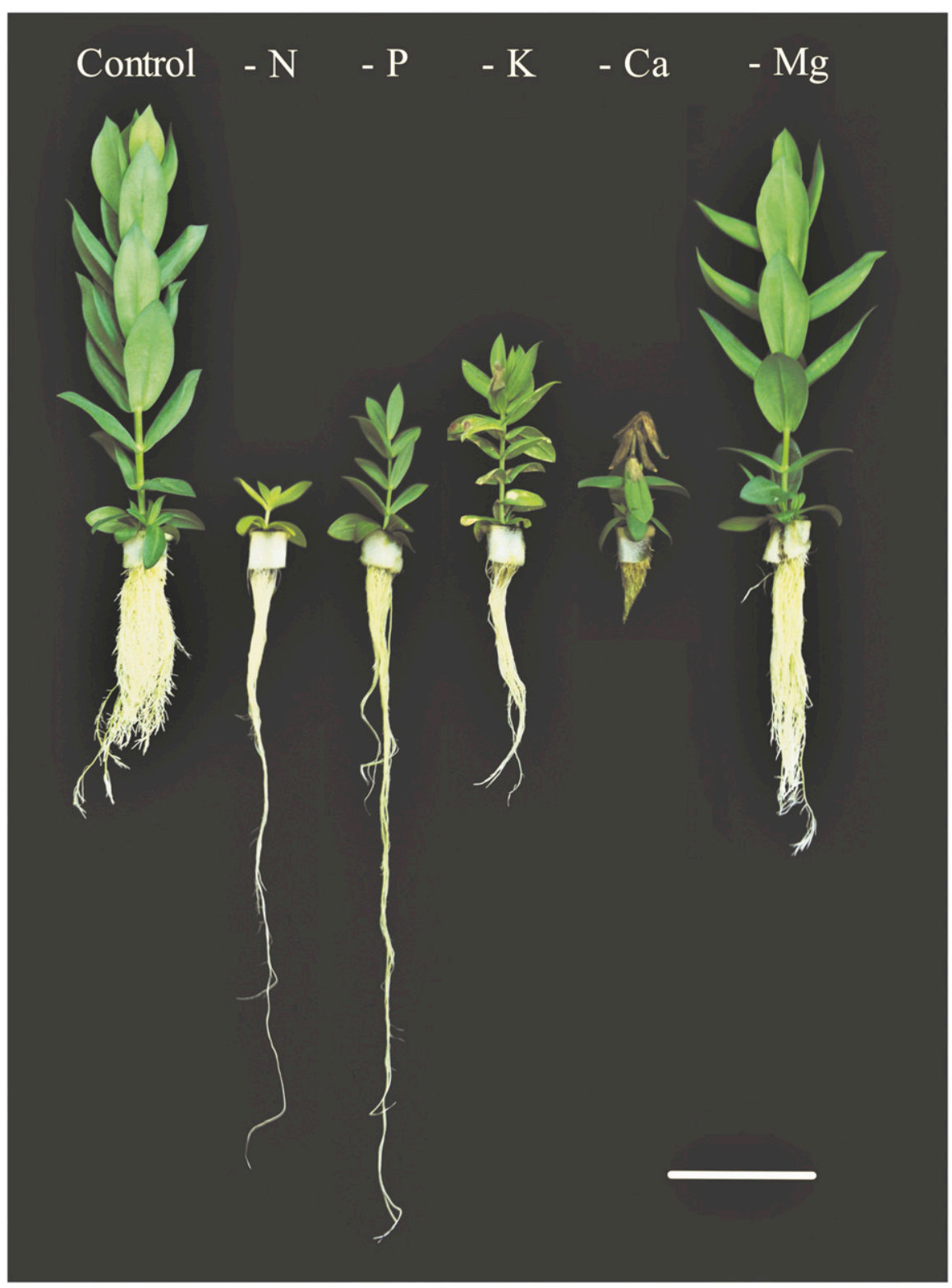

Fig. 1. Growth of Eustoma 'Umihonoka' under 1/2 strength of complete Johnson's solution (control), nitrogen $(\mathrm{N})$, phosphorus $(\mathrm{P})$, potassium $(\mathrm{K})$, calcium $(\mathrm{Ca})$, or magnesium $(\mathrm{Mg})$ deficiencies. $\mathrm{Bar}=10 \mathrm{~cm}$.

Table 5. Effects of nitrogen $(\mathrm{N})$, phosphorus $(\mathrm{P})$, potassium $(\mathrm{K})$, calcium $(\mathrm{Ca})$, or magnesium (Mg) deficiencies on $F \mathrm{v} / F \mathrm{~m}, F_{\mathrm{o}}$, and $F \mathrm{~m}$ values of the recently fully expanded leaves of Eustoma 'Umihonoka' grown hydroponically.

\begin{tabular}{lllc}
\hline Treatments & \multicolumn{1}{c}{$F_{\mathrm{V}} / F \mathrm{~m}$} & \multicolumn{1}{c}{$F_{\mathrm{O}}$} & $F \mathrm{~m}$ \\
\hline Control & 0.844 & 254.2 & $1,632.4$ \\
$-\mathrm{N}$ & $0.729 * * *$ & $328.3 * * *$ & $1,215.8 * * *$ \\
$-\mathrm{P}$ & $0.622 * * *$ & $431.5 * * *$ & $1,218.1 * * *$ \\
$-\mathrm{K}$ & $0.607 * *$ & $286.8 \mathrm{NS}$ & $1,004.9 * * *$ \\
$-\mathrm{Ca}$ & $0.002 * * *$ & $256.2 \mathrm{NS}$ & $256.4 * * *$ \\
$-\mathrm{Mg}$ & $0.841 \mathrm{NS}$ & $261.6 \mathrm{NS}$ & $1,648.7 \mathrm{NS}$ \\
\hline Ns, ${ }^{* *},{ }^{* * *}$ Nonsignificant & or significantly different
\end{tabular}
from the control by $t$ test at $P<0.01$ or 0.001 , respectively.

leaves, similar to $\mathrm{K}$ deficiency symptoms described for Phalaenopsis (Wang, 2007) and Spathiphyllum (Yeh et al., 2000). Such symptoms are often seen in Taiwan and Japan when harvesting Eustoma cut flowers, proba- bly because growers adapt preharvest-deficit irrigation, which may limit K supply or availability, whereas Eustoma plants require high $\mathrm{K}$, particularly during and after visible bud stage (de Camargo et al., 2004; Ushio and Fukuta, 2010). Reproductive growth of Phalaenopsis takes on priority for $\mathrm{K}$ that is already in other parts of a plant, resulting in necrosis and even death of the lower leaves and roots (Wang, 2007).

Shoot and root dry weight were significantly reduced, but shoot-root ratio was significantly increased by the $-\mathrm{K}$ treatment (Table 3). Hermans et al. (2006) proposed that in contrast to $\mathrm{N}$ and $\mathrm{P}$ deficiencies, the $-\mathrm{K}$ plants are less able to translocate sucrose to the root via the phloem and, thus, exhibit increased shoot-root ratio. Examples of increased shoot-root ratio under K deficiency are well documented for other species (Hafsi et al., 2014).
Potassium-deficient plants had lower $P n$ and $g_{\mathrm{S}}$, but Ci did not differ significantly, as compared with plants with complete nutrient solution (Table 4). Decreased $P n$ of K-deficient leaves in Eustoma was not only related to lower chlorophyll concentration and marginal necrosis but also to lower $g_{\mathrm{S}}$ (Tables 2 and 4), similar to reports for K-deficient Brassica napus L. (Lu et al., 2016). Potassiumdeficient plants had lower $F \mathrm{~V} / F \mathrm{~m}$ and $F \mathrm{~m}$ than the control plants (Table 5). Decreased $F \mathrm{~V} / F \mathrm{~m}$ and $F \mathrm{~m}$ of $\mathrm{K}$-deficient leaves were reported for sweetpotato [Ipomoea batatas (L.) Lam.] (Liu et al., 2017).

Calcium deficiency. Plant growth was strongly suppressed by the Ca-deficient treatment. Root growth was poor and roots were short, thickened, and brittle (Fig. 1; Table 2). Calcium deficiency induced shoot tip injury and loss of apical dominance. Tip injury was followed by the development of axillary shoots, with necrotic young leaves. The expressed $\mathrm{Ca}$ deficiency symptoms are similar to those described for other species (Hao and Papadopoulos, 2003; Yeh et al., 2000).

High relative humidity (RH) inhibits the translocation of $\mathrm{Ca}$ to the tip of the young developing leaves, resulting in tipburn of Eustoma in the greenhouse. Increased $\mathrm{Ca}$ in the nutrient solution increased leaf $\mathrm{Ca}$ concentration but had little or no effect on the incidence of tipburn (Islam et al., 2004). Severe tipburn symptoms of Eustoma are seen primarily in 1-2 weeks before flower buds become visible under $90 \%$ RH (Islam et al., 2004), suggesting that the developing flower buds might compete with the young leaves for $\mathrm{Ca}$, as reported for Chinese cabbage [Brassica rapa L. subsp. pekinensis (Lour.) Hanelt] (Pressman et al., 1993). Thus, the cause and/or severity of Ca deficiency might differ between the young vegetative Eustoma as shown in this study and the reproductive plants as reported by Islam et al. (2004).

Calcium deficiency reduced shoot and root dry weight by $78 \%$ and $72 \%$, respectively, as compared with plants with complete nutrient solution (Table 3). Increased $\mathrm{Ca}$ in the nutrient solution (Frett et al., 1988) or medium (Harbaugh and Woltz, 1991) resulted in increased Eustoma dry weight. The Ca-deficient Eustoma had lower $P n, F \mathrm{~V} /$ $F \mathrm{~m}$, and $F \mathrm{~m}$ than the control plants (Tables 4 and 5). Our results indicate that Ca plays a vital role for the growth, especially for Eustoma plants native to the alkaline soils. Gómez-Pérez et al. (2014) also reported that supplementary $\mathrm{Ca}$ can ameliorate Eustoma tolerance to alkalinity in irrigation water.

Magnesium deficiency. The Mg-deficient treatment resulted in plants with fewer nodes and did not alter plant height, leaf area, SPAD502 reading, and root length (Fig. 1; Table 2). Symptoms of slight interveinal chlorosis were observed only on lower leaves, similar to reports for other species (Farhat et al., 2016; Yeh et al., 2000).

Magnesium deficiency did not affect shoot dry weight and photosynthetic parameters measured in this study, but decreased 
a. The symptoms are expressed on the whole plant and mainly on the lower leaves.

b. The symptoms are developed on the whole plant.

c. Plant growth is strongly affected. Uniformly chlorotic young leaves, whereas the lower leaves were yellow.

cc. Plants grow slowly. No visual deficiency symptoms.

bb. The symptoms are expressed on the lower leaves.

c. Yellow specks developed on lower leaves and/or marginal necrosis.

cc. Slightly interveinal chlorosis on lower leaves.

aa. The symptoms are expressed on the upper leaves.

b. Shoot tip injury. Development of axillary shoots with necrotic young leaves.

root dry weight and thereby increased shootroot ratio as compared with the control (Tables 2-5). Cakmak and Kirkby (2008) reported that, at early stage of $\mathrm{Mg}$ deficiency, phloem export of sucrose was severely impaired, an effect that occurred before any noticeable changes in shoot growth, chlorophyll concentration, or photosynthetic activity. $\mathrm{As} \mathrm{Mg}$ is a highly mobile nutrient in plants, it is preferentially transported to source leaves to prevent severe decreases in photosynthesis. Plants lacking $\mathrm{Mg}$ are less able to translocate sucrose to the root via the phloem (Farhat et al., 2016; Hermans et al., 2006). de Camargo et al. (2004) showed that a small amount of $\mathrm{Mg}$ accumulated in young Eustoma plant, however, a relatively high $\mathrm{Mg}$ accumulation, only next to $\mathrm{N}$ and $\mathrm{K}$, for plants at $120 \mathrm{~d}$ after transplanting. We suggest that results in this study (Tables 2-5) were early effects of $\mathrm{Mg}$ deficiency and the prolonged $\mathrm{Mg}$-deficient effects require further research.

Nutrition deficiencies of Eustoma may result from improper fertilizer application and preharvest-deficit irrigation. Visual differences in response to $\mathrm{N}, \mathrm{P}, \mathrm{K}, \mathrm{Ca}$, and $\mathrm{Mg}$ deficiencies were used to create a key (Table 6), which should be a valuable diagnostic tool to identify the nutritional deficiencies of Eustoma. Growers may adopt the complete hydroponic nutrient solution for an alternative production for Eustoma to avoid soil sickness, resulting from successive cropping in greenhouses all year round. It should be recognized that under field conditions, it is rare that one element would be completely deficient as in controlled studies. Therefore, the diagnosis of the cause of an injury symptom may be more complicated than looking at the deficiency symptoms of a single element. Nevertheless, the results in this study provide a good reference for correcting the nutrition of the Eustoma being produced.

\section{Literature Cited}

Bolhar-Nordenkampf, H., S. Long, N. Baker, G. Oquist, U. Schreiber, and E. Lechner. 1989. Chlorophyll fluorescence as a probe of the photosynthetic competence of leaves in the field: A review of current instrumentation. Funct. Ecol. 3:497-514.

Cakmak, I. and E.A. Kirkby. 2008. Role of magnesium in carbon partitioning and alleviating photooxidative damage. Physiol. Plant. 133: 692-704.

Cechin, I. and T.F. Fumis. 2004. Effect of nitrogen supply on growth and photosynthesis of sunflower plants grown in the greenhouse. Plant Sci. 166:1379-1385.

Croft, B. and J. Nelson. 1998. Eustoma (lisianthus). Ball RedBook. 16th ed. Ball Publishing, West Chicago, IL.

de Camargo, M.S., L.K. Shimizu, M.A. Saito, C.H. Kameoka, S. da C. Mello, and Q.A. de C. Carmello. 2004. Crescimento e absorção de nutrientes pelo lisianthus (Eustoma grandiflorum) cultivado em solo. Hort. Bras. 22:143-146.

Farhat, N., A. Elkhouni, W. Zorrig, A. Smaoui, C. Abdelly, and M. Rabhi. 2016. Effects of magnesium deficiency on photosynthesis and carbohydrate partitioning. Acta Physiol. Plant. 38:145.

Frett, J.J., J.W. Kelly, B.K. Harbaugh, and M. Roh. 1988. Optimizing nitrogen and calcium nutrition of lisianthus. Commun. Soil Sci. Plant Anal. 19:13-24.

Gómez-Pérez, L., L.A. Valdez-Aguilar, A. SandovalRangel, A. Benavides-Mendoza, and R. MendozaVillarreal. 2014. Calcium ameliorates the tolerance of lisianthus [Eustoma grandiflorum (Raf.) Shinn.] to alkalinity in irrigation water. HortScience 49:807-811.

Hafsi, C., A. Debez, and C. Abdelly. 2014. Potassium deficiency in plants: Effects and signaling cascades. Acta Physiol. Plant. 36:1055-1070.

Hao, X.M. and A.P. Papadopoulos. 2003. Effects of calcium and magnesium on growth, fruit yield and quality in a fall greenhouse tomato crop grown on rockwool. Can. J. Plant Sci. 83:903912.

Harbaugh, B.K. 1995. Flowering of Eustoma grandiflorum (Raf.) Shinn. cultivars influenced by photoperiod and temperature. HortScience 30: 1375-1377.

Harbaugh, B.K. and S.S. Woltz. 1991. Eustoma quality is adversely affected by low $\mathrm{pH}$ of root medium. HortScience 26:1279-1280.

Hermans, C., J.P. Hammond, P.J. White, and N. Verbruggen. 2006. How do plants respond to nutrient shortage by biomass allocation? Trends Plant Sci. 11:610-617.

Hernández-Pérez, A., L.A. Valdez-Aguilar, O.G. Villegas-Torres, I. Alía-Tejacal, L.I. Trejo-Téllez, and M. de J. Sainz-Aispuro. 2016. Effects of ammonium and calcium on lisianthus growth. Hort. Environ. Biotechnol. 57:123-131.

Huang, Z.A., D.A. Jiang, Y. Yang, J.W. Sun, and S.H. Jin. 2004. Effects of nitrogen deficiency on gas exchange, chlorophyll fluorescence, and antioxidant enzymes in leaves of rice plants. Photosynthetica 42:357-364.

Islam, N., G.G. Patil, S. Torre, and H.R. Gislerød. 2004. Effects of relative air humidity, light, and calcium fertilization on tipburn and calcium content of the leaves of Eustoma grandiflorum (Raf.). Shinn. Europ. J. Hort. Sci. 69:29-36.

Johnson, C.M., P.R. Stout, T.C. Broyer, and A.B. Carlton. 1957. Comparative chlorine requirements of different plant species. Plant Soil 8:337-353.

Kirkby, E.A. and K. Mengel. 1967. Ionic balance in different tissues of the tomato plant in relation to nitrate, urea, or ammonium nutrition. Plant Physiol. 42:6-14.

Liu, M., A.J. Zhang, X.G. Chen, R. Jin, H.M. Li, and Z.H. Tang. 2017. The effect of potassium deficiency on growth and physiology in sweetpotato [Ipomoea batatas (L.) Lam.] during early growth. HortScience 52:1020-1028.

Lu, Z.F., T. Ren, Y.H. Pan, X.K. Li, R.H. Cong, and J.W. Lu. 2016. Differences on photosynthetic limitations between leaf margins and leaf centers under potassium deficiency for Brassica napus L. Sci. Rpt. 6:21725, doi: 10.1038/ srep21725.

Mak, A.T.Y. and D.M. Yeh. 2000. Nitrogen nutrition of Spathiphyllum 'Sensation' grown in sphagnum peat-and coir-based media with two irrigation methods. HortScience 36:645-649.

Marchese, J.A., I. Katz, A.P. Sousa, and J.D. Rodrigues. 2005. Gas exchange in lisianthus plants (Eustoma grandiflorum) submitted to different doses of nitrogen. Photosynthetica 43:303-305.

Mollier, A. and S. Pellerin. 1999. Maize root system growth and development as influenced by phosphorus deficiency. J. Expt. Bot. 50:487-497.

Pressman, E., R. Shaked, and L. Arcan. 1993. The effect of flower-inducing factors on leaf tipburn formation in Chinese cabbage. J. Plant Physiol. 141:210-214.

Takezaki, A., Y. Yoshida, and M. Masuda. 2004. Leaf structure and photosynthetic properties in rosetting and bolting Eustoma plants. J. Jpn. Soc. Hort. Sci. 73:287-292.

Terry, N. and A. Ulrich. 1973. Effects of phosphorus deficiency on the photosynthesis and respiration of leaves of sugar beet. Plant Physiol. $51: 43-47$

Ushio, A. and N. Fukuta. 2010. Effect of nitrogen fertilization levels in nutrient solution applied before/after flower budding on blasting in winter-flowering of Eustoma grandiflorum (Raf.). Shinn. Hort. Res. (Japan) 9:191-196.

Wang, Y.T. 2007. Potassium nutrition affects Phalaenopsis growth and flowering. HortScience 42:1563-1567.

Xu, H.X., X.Y. Weng, and Y. Yang. 2007. Effect of phosphorus deficiency on the photosynthetic characteristics of rice plants. Russ. J. Plant Physiol. 54:741-748.

Yeh, D.M., L. Lin, and C.J. Wright. 2000. Effects of mineral nutrient deficiencies on leaf development, visual symptoms and shoot-root ratio of Spathiphyllum. Scientia Hort. 86:223-233. 